\title{
Creativity in The Emergence Of Batik Modern Style In Surakarta
}

\author{
Sujadi R. Hidayat ${ }^{1}$, Dharsono ${ }^{2}$, Rustopo ${ }^{3}$ \\ \{sujadi_fsrd@staff.uns.ac.id\} \\ ${ }^{1}$ Craft Departement, Universitas Sebelas Maret \\ ${ }^{23}$ Postgraduate Program, Indonesia Institute of The Arts Surakarta
}

\begin{abstract}
In Surakarta around 1970, a unique style of Batik emerged. The Batik is called Modern Style Batik. The visual style that appears in Batik is very different from other Batik styles that have appeared in Surakarta. This study discusses creativity in the emergence of Modern Style Batik in Surakarta. The objective to be achieved in this study is to explain the creative activities and the factors behind them so that Modern Style Batik appears in Surakarta. The study was conducted with a qualitative research method with a phenomenological approach. Data sources used in the form of informants or informants. The results of this study explain that creative activities in Modern Style Batik in Surakarta are connecting traditional Batik with abstract expressionism-style from modern art.
\end{abstract}

Keywords: Batik, Modern Style, Creativity, Craft, Modern Art

\section{Introduction}

Surakarta is one of the centers of Batik in Indonesia. The existence of Batik in Surakarta existed more than three centuries ago and is still maintained. Dharsono [1] explains the dynamics of Batik in Surakarta, that XVI century Batik is a luxury trade commodity, which only rich people can have. Batik is a special item in the community so that in the XVIII century the palace (Surakarta palace) developed Batik. The palace began to gather Batik experts to produce Batik in the palace. The palace began to create new Batik motifs now known as Keraton Batik or classical Batik motifs. In addition to creating classical Batik motifs, the king also regulates the use of Batik motifs. In the twentieth-century palace, Batik production has decreased so that there are Batik areas outside the palace. These Batik areas are centers of Batik production that support the existence of Batik in Surakarta to date [2][3].

Batik life in Surakarta takes place so dynamically following the times and the environment. This makes the style of Batik that appears in Surakarta is also so diverse. Batik styles that have emerged in the Batik world in Surakarta include Kasunanan style, Mangkunegaran style, Wonogiren style, Sudagaran style, Petanen or Rural style, Dutch style, Tiga Negeri style, Raya Indonesia style, and Modern style [4].

Modern style Batik that emerged around 1970 is the most unique evolution of the Batik style in Surakarta, both from the visual, technical, and historical aspects of its emergence and development. Modern style Batik is a Batik product with a shape, structure, motif and color 
composition that is different from traditional Batik. This Batik style can be said as 'tradition of the new', namely the pattern of the birth of a new art style which was initially rejected and then accepted by the community as the latest innovation[5]. Initially, this Batik style was opposed because it was considered antithetical to calcic or traditional Batik. Then, because of the influence of the times and the synthesis of tradition Batik was finally considered as an innovative Batik.

Modern style Batik in Surakarta emerged as a result of creativity. Creativity is the ability to produce strange works that are original, unexpected and suitable that is useful, able to adapt[6]. Creativity is the essence of art[7]. Marianto further explained creative people may be disturbed when asked how they create things because they do not make anything, but connect their experiences and then arrange them into new things. Creativity is a matter of connecting things that were not connected. The interconnectedness of various things that made modernstyle Batik born in Surakarta is an important case to study. Based on this background, this study aims to find out what things are related and connected to appear modern style Batik in Surakarta.

\section{Research Method}

This study applies qualitative research methods. This method will explore and understand the meaning of several individuals or groups of people. This study applies an inductive-style research perspective, focuses on the meaning of the individual, and translates the complexity of an issue [8].This study uses a phenomenological approach, in which researchers describe the experience of human life about certain phenomena. This design has a strong philosophical and involves conducting interviews[9][10]. The speakers were chosen from people who played a direct role in the emergence of modern style Batik in Surakarta. Data validity uses data source triangulation techniques, where information from one source is confirmed with information from other sources[11].

\section{Results And Discussion}

Information data obtained from interviewees by interviewing techniques of three early generation Batik makers who gave rise to and developed modern style Batik in Surakarta. Two of them, Sarjono and Wiryanto, claimed to be the originators of the emergence of modern style Batik in Surakarta. The interview conducted in early 2019 was aimed to find out the knowledge and experience possessed by informants related to the creation of modern style Batik. Sarjono explained that he knew Batik from parents. His mother was a Batik worker as a Batik worker whose job was to carve batik wax onto the surface of the cloth with a canting tool to form the desired motif. Batik makers often bring home their work to be done at home. Sarjono knew and knew about Batik but could not make Batik-like Batik at that time. His knowledge of Batik at that time was limited to the process of pasting batik wax on the surface of the Mori and knowing the function of batik wax as a color barrier and forming Batik motifs.

Based on the interview data above, it can be seen that Sarjono created modern style Batik armed with experience and knowledge about Batik from his parents, about painting from the results of learning with Doellah, and about creativity from the results of association with 
friends, art enthusiasts, and artists. Also, Sarjono's creativity in bringing up modern style Batik because there is an economic need to produce works that sell for sale.

Wiryanto is the son of a stamped Batik entrepreneur, so he is very familiar with Batik. Because the production site is in the same location as the residence, Wiryanto knows the process of making printed Batik from the beginning to the end. He has quite a lot of knowledge and experience about Batik materials and processes. Wiryanto had the urge to think of Batik when the cap Batik business began to decline because it had to compete with printing. Wiryanto told, the emergence of the idea to make modern style Batik originated from people from Jakarta coming to the house to learn Batik. Because the Jakarta people did not know about traditional Batik motifs when trying to make Batik he made motifs that were very different from Surakarta's traditional motifs. The Jakarta-made Batik opened Wiryanto's mind that Batik can be used to make different forms of traditional motifs. Besides this, Wiryanto's inspiration in creating modern-style Batik was a painting by Pablo Picasso. Wiryanto learned about Pablo Picasso's painting from a book he had read. Based on these two inspirations, Wiryanto created a modern style of Batik which at that time was called abstract Batik or oldfashioned Batik.

Based on the interview data above, it is known that Wiryanto created modern-style Batik armed with knowledge and experience about Batik from his parents who were stamped Batik entrepreneurs, about Batik innovation opportunities from the Jakarta people, and about painting from books describing Picasso's paintings. Also, Wiryanto's creativity in bringing up modern style Batik because there was an economic need to push for innovation in his parents' stamped Batik business began to decline

Saud Effendi is the son of a Batik entrepreneur from Laweyan. Although geographically it is not included in the Laweyan Village area, now known as Kampoeng Batik Laweyan, it is socially and culturally included in the Laweyan Batik industrial area. Like most Batik entrepreneurs in Laweyan, Saud Effendi's residence and his parents' Batik factory are in one location. He is very familiar with the world of Batik because in his residence there is a Batik factory and the environment is the center of the Batik industry in Surakarta. Saud Effendi is a graduate of the Indonesian Academy of Fine Arts (ASRI) Yogyakarta in the field of painting.

Saud Effendi became active in the Batik world when he had to continue his parents' Batik business, where none of his brothers were willing to continue. At that time, Batik business conditions were sluggish because it could not compete with textile printing. Although not the first person to bring up modern style Batik in Surakarta, Saud Effendi is one of the early generations of Batik skipper who produces this type of Batik.

Saud Effendi explained that he created modern style Batik as a "gallery work". Saud Effendi's Batik products have two categories, namely "kitchen works" and "gallery works". Batik "kitchen work" is made based on taste and market needs, both in quality and price, to maintain business continuity. Batik "gallery works" are works with special designs and special quality, as a form of Batik innovation to find new market opportunities or certain class consumers. Saud Effendi said, "because of the demand to maintain the Batik business amid competition with printing, efforts have emerged to create new Batik motifs that are different from the results of printing and cannot be imitated by a printing machine. Against this background, new motifs developed with different shapes and patterns from traditional Batik forms and patterns ".

Based on the interview data above, it is known that Saud Effendi created modern style Batik armed with knowledge and experience about Batik from his parents who were a Batik skipper and from the environment which was the center of the Batik industry in Surakarta. Knowledge and experience of art and creativity are mostly obtained from studies at ASRI 
tertiary institutions. Also, Saud Effendi's creativity in bringing up modern style Batik because there is an economic need to push Batik product innovations to fight or survive amid the printing industry.

The data obtained from the interview are still subjective. To obtain objective data, it is necessary to find the data slices from the three data sources. There is the same experience and knowledge from the three resource persons who influence their creativity in producing modern style Batik. All three speakers know and know about Batik, even though their level of knowledge is different.

All three speakers know modern art and are happy to do creative activities related to Batik. Saud Effendi had art knowledge from the results of studies at ASRI, Sarjono from studying painting to Doellah, a national painter, and Wiryanto learned the art from reading books about Picasso. All three speakers have the same background in developing modern style Batik, namely economic needs. Saud Effendi and Wiryanto have economic needs to continue their parents' Batik business. Sarjono has economic needs because of the difficulty in selling his paintings. On social background factors, the three speakers have in common, which are both not from the aristocratic group. Saud Effendi and Wiryanto from the business group, while Sarjono from the ordinary community. They are both not from the aristocratic class so that in making changes to the tradition will be more daring because there is no cultural burden. The nobility, an established group, will be more difficult to accept changes in their traditions.

The creativity that occurs in the emergence of modern style Batik in Surakarta is connecting the traditional Batik with modern art. Modern style Batik featuring abstract Expressionism-style. Expressionism-Abstract is a modern art style that developed from America in 1942. The style of displaying lines and colors tends not to be geometric, displaying bursts, plots, and expressive forms[12]. The visual style of Abstract Expressionism is presented on the fabric surface using Batik techniques (resist dyeing using night) so that Modern Style Batik appears.

Creativity is bringing up modern style Batik in Surakarta is a form of Batik preservation creatively. This is in accordance with the statement of Reeves and Plets [13] that in the legal context those who control the interpretation of narrative inheritance are inherited from inheritance control. Modern style Batik in Surakarta is finally considered a successful innovation because of the negotiation of interests and tastes between craftsmen, users, and rulers. Such negotiations can work well where the involvement of traditional carriers actively differs from unbalanced hierarchies or power relations, thereby giving importance to the grassroots strategy of craftsmen who build their own "heritage" [14][15] [16].

\section{Conclusion}

The creativity that occurs in the emergence of modern style Batik in Surakarta is connecting the traditional Batik with modern art. The visual style of Abstract Expressionism is presented on the fabric surface using Batik techniques so that Modern Style Batik appears.

Factors that influence the creativity of the emergence of Modern Style Batik in Surakarta are experience and knowledge as well as social background and the needs of the creator of the Batik style. These factors include: 1) Having knowledge and experience about Batik and modern art; 2) Happy with creative activities; 3) The results of creativity have an economic impact; 4) There are no significant sociocultural burdens when taking actions that deviate from tradition. 


\section{Acknowledgement}

This research is part of the research conducted for the study of doctoral programs at the Postgraduate Program at the Indonesia Institute of The Arts Surakarta. Our gratitude goes to Sebelas Maret University for funding the implementation of doctoral program studies and funding for the implementation of this research.

\section{References}

[1] Dharsono, Seni Rupa Modern. Bandung: Rekayasa Sains, 2017.

[2] S. Doellah, Batik: Influence of Times and Environment. Surakarta: Batik Danar Hadi, 2002.

[3] K. Honggopuro, Bathik sebagai Busana dalam Tatanan dan Tuntunan. Surakarta: Yayasan Peduli Keraton Surakarta, 2002.

[4] I. Tirta, Batik: Sebuah Lakon. Jakarta: Gaya Favorite Press, 2009.

[5] Dharsono, Budaya Nusantara: Kajian Konsep Mandala dan Konsep Tri-loka terhadap Pohon Hayat pada Batik Klasik. Bandung: Rekayasa Sains, 2007.

[6] Sterberg and Lubart, "The Concept of Creativity: Perpective and Paradicms," in Handbook of Creativity, R. J. Sternberg, Ed. New York: Cambridge University, 1999.

[7] M. D. Marianto, Art and Life Force in a Perpective Quantume. Yogyakarta: Scrintto Books Publisher, 2017.

[8] J. W. Creswell, Research Design: Qualitative, Quantitative, and Mixed Methods Approaches. Fourth Edition, Fourth. SAGE Publication, Inc., 2014.

[9] A. Giorgi, The Descriptive Phenomenological Method in Psychology: A Modified Husserlian Approach. Pittsburgh: Duquesne University Press., 2009.

[10] C. Moustakas, Phenomenological research methods. Thousand Oaks, CA: Sage, 1994.

[11] H. B. Sutopo, Metode Penelitian Kualitatif: Dasar Teori dan Terapannya dalam Penelitian. Surakarta: UNS Press, 2002.

[12] Dharsono, Kreasi Artistik: Perjumpaan tradisi modern dalam paradigma kekaryaan seni. Surakarta: Citra Sains, 2016.

[13] K. Reeves and G. Plets, "Cultural Heritage as a Strategy for Social Needs and community Ident," in A Companion to Heritage Studies, W. Logan, M. N. Craith, and U. Kockel, Eds. Chichester, 2015, pp. 203-214.

[14] M. Varutti, "Crafting Heritage: Artisans and the Making of Indigenous Heritage in Contemporary Taiwan," Int. J. Herit. Stud., vol. 21, pp. 1036-1049, 2015.

[15] Chamithri Greru and B. Kalkreuter, "Design and the Evolving Tradition of Sanganer Hand Block Printing: Formation and Negotiation of Artisanal Knowledge and Identities Against the Backdrop of Intangible Cultural Heritage," J. Mod. Cr., vol. Volume 10, no. 2, pp. 137-156, 2017.

[16] K. Saddhono, S. T. Widodo, M. T. Al-Makmun, and M. Tozu, "The study of philosophical meaning of Batik and Kimono motifs to foster collaborative creative industry," Asian Soc. Sci., vol. 10, no. 9, 2014. 